DOI: https://doi.org/10.15407/techned2018.06 $: \underline{085}$

\title{
TOPOLOGY OF FILTER-COMPENSING DEVICES FOR IMPROVING THE SPECTRUM OF INPUT CURRENT OF POWER SOURCES IN ELECTROTHERMIC INSTALLATIONS ON THE PRODUCTION OF BASALT SUPERTON FIBER
}

$\quad$ Journal
Publisher
ISSN
Issue
Pages

\author{
Tekhnichna elektrodynamika \\ Institute of Electrodynamics National Academy of Science of Ukraine \\ 1607-7970 (print), 2218-1903 (online) \\ No 6, 2018 (November/December) \\ $85-88$
}

\author{
Authors \\ I.V. Volkov ${ }^{\star}$, V.P. Styazhkin ${ }^{\star *}$, P.P. Podeiko* \\ Institute of Electrodynamics National Academy of Sciences of Ukraine, \\ pr. Peremohy, 56, Kyiv, 03057, Ukraine, \\ e-mail: tems@ukr.net \\ * ORCID ID : http://orcid.org/0000-0002-0696-0382 \\ ** ORCID ID : http://orcid.org/0000-0003-0602-1112 \\ *** ORCID ID : http://orcid.org/0000-0001-9201-102X
}

\begin{abstract}
To improve the spectrum of the power supply input current in electrothermal installations for the BSTF production, the new approach to current correction in the spinneret plate heating mode, which uses combined circuit of the power source by the thyristor regulator system-a special transformer-an active current corrector, is developed. The diagrams of the corrector current and the spectrograms of the input current are analyzed, which confirm the effectiveness of the
\end{abstract}


proposed solution. References 7, figures 4, table 1.

Key words: thyristor current regulator, special transformer, correction of current shape, hybrid filter, total harmonic distortion.

Received: 02.03.2018

Accepted: 03.05.2018

Published: 23.10 .2018

\section{References}

1. Styazhkin V.P., Podeiko P.P. Optimum control of the electrotechnological installation for the production of basaltic superthin fiber. Vestnik Natsionalnogo tekhnicheskogo universiteta KhPI. Tematicheskii vypusk Problemy avtomatizi-rovannogo elektroprivoda. Teoriia i praktika . 2015. No 12 (1121). Pp. 124-127. (Rus)

2. Zainal Salam, Tan Perng Cheng, Awang Jusoh. Harmonics Mitigation Using Active Power Filter: A Technological Review. Department of Energy Conversion, University Technology Malaysia . 2006. No 2. Pp. 17-26.

3. Komarov M.S., Golovko O.O., Bulatov A.Y., Podeiko P.P. Energy-saving technologies in computer classes and educational laboratories of educational institutions. Visnyk Kyivskoho Natsionalnoho Universytetu tekhnolohii ta dyzainu

. 2013. No 6. Pp. 278-286. (Ukr)

4. Kolb A.A. Hybrid filters in power quality control devices. Elektromekhanichni $i$ enerhozberihaiuchi systemy

Vyp. 3/2012 (19). Pp. 250-253. (Rus)

5. Welding transformer TVK-75 UHL4 for contact electrowelding machines. Pasport. 8 p.

6. Short course of training operators, debuggers, masters of production of basalt super-fine staple fibers (BSTS). Quality management system. Instruction. VKP Chernivetskii zavod 
teploizoliatsiinykh materialiv. 2014. 47 p. (Ukr)

7. Lypkivskyi K.O., Khalikov V.A., Mozharovskyi A.G. Phase voltage regulation with keys with natural switching and its research in the MATLAB system. Tekhnichna Elektrodynamika.

Tematychnyi vypusk Problemy suchasnoi elektrotekhniky. 2002. Pp. 72-79. (Ukr)

PDF 